Pobrane z czasopisma Annales H - Oeconomia http://oeconomia.annales.umcs.pl Data: 26/04/2023 14:52:54

DOI:10.17951/h.2017.51.5.59

\begin{tabular}{lcl}
\hline & A N N A L E S \\
UNIVERSITATIS MARIAE CURIE-SKŁODOWSKA \\
LUBLIN - POLONIA \\
VOL.LI, 5 & SECTIO H \\
\hline
\end{tabular}

Kazimierz Pulaski University of Technology and Humanities in Radom.

Faculty of Economic and Legal Sciences

SŁAWOMIR BUKOWSKI

s.bukowski@uthrad.pl

\title{
Integration of Polish Equity and Debt Securities Market with Foreign Market and Economic Growth in Poland
}

Integracja polskiego rynku papierów udziałowych i rynku papierów dłużnych z rynkami zagranicznymi a wzrost gospodarczy w Polsce

Keywords: financial integration; equity securities; debt securities; economic growth; GMM; econometric model

Słowa kluczowe: integracja finansowa; papiery udziałowe; papiery dłużne; wzrost gospodarczy; GMM; model ekonometryczny

JEL Code: C58; F43; E44;F15; F36; G15

\section{Introduction}

The research results which are presented in this paper aimed to verify the theory which claims that there is a significant relationship between financial market integration on international scale, financial development and economic growth. Our research focused not on the entire financial market but on the segment of equity securities (shares and investment certificates) and debt securities (corporate bonds, treasury bonds, T-Bills). The research was limited to the Polish market of securities and its integration with foreign markets (not only EU financial market but also global financial market) as well as the influence of the degree of this integration on the financial development and economic growth. A research hypothesis was formulated that the integration of the Polish equity securities and debt securities markets with foreign 
markets has a statistically and economically significant impact on the development of the country's capital market and economic growth. The ratio of the sum of the Polish portfolio investment in equity securities abroad and foreign portfolio investment in equity securities in Poland to GDP was adopted as a measure of the equity securities market integration. Analogically, in the case of debt securities market, ratio of the sum of the Polish portfolio investment in debt securities abroad and foreign portfolio investment in debt securities in Poland to GDP was adopted as a measure of integration. To measure the degrees of the capital market development and financial development we adopted the ratio of stock market capitalization to GDP and the ratio of bond market capitalization to GDP. In our research we employed econometric model estimated with the use of the generalized method of moments (GMM).

\section{Integration of financial markets and economic growth in view of theory and research}

L. Baele, A. Ferrando, P. Hördal, E. Krylova and C. Monnet [2004, pp. 6-7] proposed a broad definition of financial market integration. From their definition it can be concluded that financial markets are integrated if all potential participants of a transaction reveal the same characteristics:

- they are subject to the same rules when they decide to take part in equity trading,

- they have the same access to equity,

- they are treated in the same way when involved in dealings on the market.

It is a broader definition than the ones based on the law of one price. It also allows for using quantitative indicators as measures of financial market integration, which unlike the indicators based on the law of one price are more useful for investigations of the relationship between financial integration and economic growth due to their time variability ${ }^{1}$.

Effects of international integration of financial markets are connected with the impact of integration processes on economic growth and economic stabilization or destabilization.

The first issue is related to the problem of financial development and relationships between financial development and economic growth. According to R. Levine, "Financial development occurs when financial instruments and financial intermediaries improve information effects, increase the discipline of financial market participants and reduce transaction costs and, in this way, cause that the following five functions are better fulfilled:

- providing ex ante information on possible investment and capital allocation,

- monitoring investment and enhancing corporate governance,

\footnotetext{
1 More on the topic: [Bukowski, 2011, pp. 32-55; Coricelli, Masten, Masten, 2008; Sum, 2012].
} 
- facilitating trading in financial instruments, diversifying risk and risk management,

- mobilization and amassment of savings,

- facilitating exchange of goods and services.

Each of these functions can affect decisions on savings and investment and, consequently, economic growth" [Levine 2005, pp. 5-7].

According to J. Greenwood and B. Jovanovic, economic growth and financial development are inextricably linked. "Economic growth provides the wherewithal to develop financial structure, while financial structure in turn allowed for higher growth since investment could be more efficiently undertaken" [Greenwood, Jovanovic, 1989, p. 25]. This type of view is also, to a large extent, confirmed by empirical studies [see more: Bukowski, 2011, pp. 29-32].

In Poland, studies concerning the impact of financial market development on economic growth were conducted by W. Dębski, I. Maciejczyk, P. Wdowiński [2010], W. Dębski, I. Bujnowicz [2008] and S.I. Bukowski [2011, 2013]. The results of their work indicate a statistically significant and theory conformable, mutual dependence between financial market development, and first of all, the equity market, and economic growth in Poland, and in the case of S.I. Bukowski's studies [2011] - in the euro area.

Integration of financial markets on the international scale affects economic growth through financial development (including financial markets) stimulation, which is illustrated in Fig. 1.

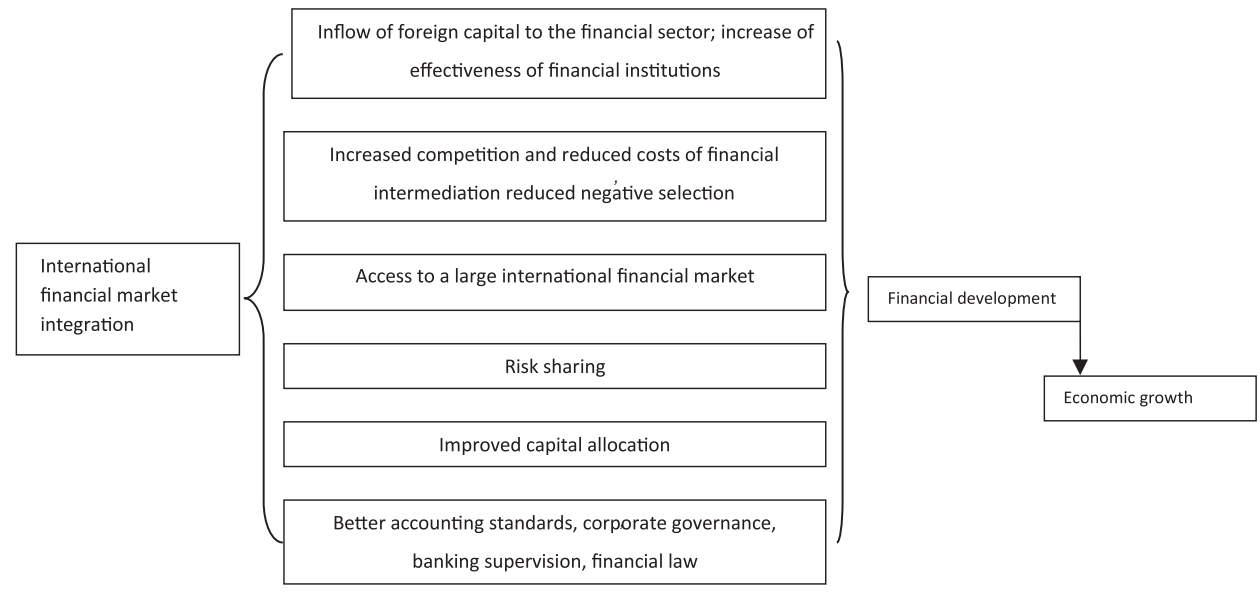

Fig. 1. Theoretical relationship between international financial market integration and financial development and economic growth

Source: [Bukowski, 2011, p. 35].

International financial market integration affects development of local financial markets through increased investment in the financial sector and increased depth of financial markets. Moreover, the inflow of direct investment to the financial sector is 
followed by increased effectiveness of financial institutions (inflow of new technologies). Competitive pressure leads to reduced adverse selection and reduced financial agency costs, as well as increased capital availability for enterprises and households. Better capital availability for enterprises and households results also from access to a large international financial market.

F. Coricelli, A. Brezigar and I. Masten [2008] studied the impact of financial integration on financial development and economic growth.

The studies covered the EU-27 countries, Croatia, Iceland, Norway, Russia and Ukraine and the period of 1996-2006. The results of study confirmed the positive impact of both financial development and financial integration on economic growth.

K. Sum [2012] carried out research covering 69 countries and annual data for the period 1975-2007. As a measure of financial integration she adopted the ratio of total foreign liabilities to GDP as the main independent variable explaining economic growth in the model. The results indicate discrepancies between the theory which claims a positive and economically significant impact of financial integration on economic growth, but their confirmation, as she maintains, needs further research.

Ch. Friedrich, I. Schnabel and J. Zettelmeyer [2010] in their investigations applied the R.G. Rajan and L. Zingales methodology [1998] based on examining the effect of financial integration and financial development on production growth in economic sectors. Their research covered developing countries commonly referred to as emerging markets and the data for the period 1998-2005. As a measure of financial integration they adopted the ratio of total foreign assets to GDP, the ratio of foreign debt to GDP, and the ratio of foreign direct investment to GDP. On the basis of analysis of the econometric model estimation results they proved that the impact of financial market integration on economic growth is not only statistically significant but also economically very important.

It is worth mentioning that there are very few analyses of the impact of financial market integration on economic growth. What is more, like in the works of the above quoted authors, majority of analyses use quantity based measures of financial integration.

\section{Statistical data}

In our research we used annual data for the period 1994-2015. The sources of data was following: the ECB Statistical Data Warehouse, AMECO, Warsaw Stock Exchange database, National Bank of Poland's database (the balance of payments statistics - international investment position), Financial Structure Dataset, revised September 2015, World Bank.

The values related to real GDP and real net investment (NFCF) come from the AMECO database (available data in constant prices from 2010).

The data regarding Polish portfolio investment abroad and foreign portfolio investment in Poland related to equity securities were expressed at constant prices 
from 2010. They come from the National Bank of Poland's database (the balance of payments statistics - international investment position).

Indicators of the equity market development and bond market development were constructed by the authors of database Financial Structure Dataset in the following way [see: Beck, Al-Hussainy, 2015]:

$S T O C K$ - the ratio of the stock market capitalization to GDP; BOND the ratio of bond market capitalization to GDP

$\left\{0,5\left[\mathrm{STOCK}_{\mathrm{t}} / \mathrm{P}_{-} \mathrm{e}_{\mathrm{t}}+\mathrm{STOCK}_{\mathrm{t}-1} / \mathrm{P}_{-} \mathrm{e}_{\mathrm{t}-1}\right]\right\} / \mathrm{GDP} / \mathrm{P} \_\mathrm{a}_{\mathrm{t}}$, where: $P_{-} e_{t}-$ end-of period CPI, $P e_{t-1}-$ beginning of year CPI, $P_{-} a_{t}-$ annual average CPI.

$\left\{0,5\left[\mathrm{BOND}_{\mathrm{t}} / \mathrm{P}_{-} \mathrm{e}_{\mathrm{t}}+\mathrm{BOND}_{\mathrm{t}-1} / \mathrm{P}_{-} \mathrm{e}_{\mathrm{t}-1}\right]\right\} / \mathrm{GDP}_{\mathrm{t}} / \mathrm{P}_{-} \mathrm{a}_{\mathrm{t}}$, where: $P_{-} e_{t}-$ end-of period CPI, $P \_e_{t-1}-$ beginning of year CPI, $P \_a_{t}-$ annual average CPI.

It is worth emphasizing here that the indicators for capitalization in the corporate bond market and treasury bond market were summed up.

In a similar way these indicators were estimated for the equity securities and treasury bond securities for the years 2014-2015 basing on the Warsaw Stock Exchange database.

\section{Model}

A model consisted of three equations specified below:

$$
\begin{aligned}
& \Delta \operatorname{lnGDP} P_{t}=\alpha_{10}+\alpha_{11} \Delta \ln A I_{t}+\alpha_{12} \Delta \ln D I_{t}+\alpha_{13} \Delta \operatorname{lnSTOCK_{t}+} \\
& \alpha_{14} \Delta \ln B O N D_{t}+\alpha_{15} \Delta \ln N F C F_{t}+\alpha_{16} \Delta \ln G D P_{t-1}+\alpha_{17} t+\varepsilon_{1 t} \\
& \Delta \operatorname{lnSTOCK}{ }_{t}=\alpha_{20}+\alpha_{21} \Delta \ln A I_{t}+\alpha_{22} \Delta \operatorname{lnSTOCK_{t-1}}+\alpha_{23} \Delta \ln B O N D_{t}+ \\
& \alpha_{24} \Delta \operatorname{lnNFCF} F_{t}+\alpha_{25} t+\varepsilon_{2 t} \\
& \Delta \operatorname{lnBOND_{t}}=\alpha_{30}+\alpha_{31} \Delta \ln D I_{t}+\alpha_{32} \Delta \ln D I_{t-1}+\alpha_{33} \Delta \operatorname{lnSTOCK_{t}}+ \\
& \alpha_{34} \Delta \ln B O N D_{t-1}+\alpha_{35} \Delta \operatorname{lnNFCF_{t}}+\alpha_{36} \Delta \ln G D P_{t}+\alpha_{37} t+\varepsilon_{3 t}
\end{aligned}
$$

where:

$\Delta l n-\log$ differences of selected variables

$G D P_{t}$ - real GDP - dependent variable in first equation

$S T O C K_{t}$ - stock market capitalization/GDP - dependent variable in second equation $B O N D_{t}$ - bond market capitalization/GDP - dependent variable in third equation

Regressors:

$A I_{t}$ - indicator of equity securities market integration

$D I_{t}$ - indicator of debt securities market integration 
Instruments:

$S T O C K_{t}$ - stock exchange market capitalization/GDP

$B O N D_{t}-$ bond market capitalization/GDP

$N F C F_{t}$ - real net investment/ GDP

$t$ - time

$\varepsilon_{t}-$ residuals

The model was estimated using the two-step Generalized Method of Moments (2-step GMM).

\section{Model estimation results}

The Engle-Granger cointegration test was carried out for all variables of the model. Tab. 1 contains final results of the test.

Tab. 1. Augmented Dickey-Fuller test with constant and trend for uhat including one lag of (1-L)uhat (max was 1, criterion AIC) sample size 19

\begin{tabular}{|l|}
\hline unit-root null hypothesis: $\mathrm{a}=1$ \\
\hline model: $(1-\mathrm{L}) \mathrm{y}=(\mathrm{a}-1) * \mathrm{y}(-1)+\ldots+\mathrm{e}$ \\
\hline 1st-order autocorrelation coeff. for e: -0.053 \\
\hline estimated value of $(\mathrm{a}-1):-1.432$ \\
\hline $\begin{array}{l}\text { test statistic: tau_ct }(6)=-4.6921, \text { critical value }=-3.6 \text { with significance level }=5 \%, \text { and critical value }=-4.38 \\
\text { with significance level }=1 \% .\end{array}$ \\
\hline asymptotic p-value: 0.1023 \\
\hline
\end{tabular}

Source: own calculation.

The tested time series are co-integrated (see Tab. 1). Tab. 2, 3 and 4 contain the model estimation results.

Tab. 2. Equation 1: 2-step GMM, using observations 1996-2015 (T=20)

Dependent variable: ld_GDP

Instrumented: ld_AI ld_DI

Instruments: const ld_STOCK ld_BOND ld_NFCF time ld_GDP_1

HAC standard errors, bandwidth 2 (Bartlett kernel)

\begin{tabular}{|l|c|c|c|c|l|}
\hline & Coefficient & Std. Error & $z$ & $p$-value & \\
\hline ld_AI & 0.0307765 & 0.00745787 & 4.1267 & $<0.0001$ & $* * *$ \\
\hline ld_DI & 0.0459263 & 0.0109365 & 4.1994 & $<0.0001$ & $* * *$ \\
\hline Const. & -0.0475347 & 0.0438842 & -1.0832 & 0.2787 & \\
\hline Mean dependent var. & 0.040536 & & S.D. dependent var. & 0.017289 \\
\hline
\end{tabular}

$* * *$ the variable is significant at the significance level of $0.01, * *$ the variable is significant at the significance level of $0.05, *$ the variable is significant at the significance level of 0.1

Source: own calculation. 
GMM criterion: $Q=0.0645452(T Q=1.2909) \mathrm{J}$ test: Chi-square(3) $=1.2909$ [0.7313]

LM test for autocorrelation up to order 1 -

Null hypothesis: no autocorrelation

Test statistic: $L M F=1.12763$

with $p$-value $=P(F(1.17)>1.12763)=0.304049$

Test for ARCH of order 1 -

Null hypothesis: no ARCH effect is present

Test statistic: $L M=0.00350861$

with p-value $=P($ Chi-square $(1)>0.00350861)=0.952766$

Test for normality of residual -

Null hypothesis: error is normally distributed

Test statistic: Chi-square(2) $=0.485827$

with $p$-value $=0.784339$

Tab. 3. Equation 2: 2-step GMM, using observations 1996-2015 (T=20)

Dependent variable: ld_STOCK

Instrumented: ld_AI

Instruments: const ld_BOND ld_NFCF time ld_STOCK_1

HAC standard errors, bandwidth 2 (Bartlett kernel)

\begin{tabular}{|c|c|c|c|c|c|}
\hline & Coefficient & Std. Error & $z$ & $p$-value & \\
\hline Const. & 0.00232714 & 0.0367524 & 0.0633 & & \\
\hline 1d_AI & 0.609243 & 0.127488 & 4.7788 & $<0.0001$ & *** \\
\hline \multicolumn{2}{|c|}{ Mean dependent var. } & 0.127697 & \multicolumn{2}{|c|}{ S.D. dependent var. } & 0.230312 \\
\hline
\end{tabular}

$* * *$ the variable is significant at the significance level of $0.01, * *$ the variable is significant at the significance level of $0.05, *$ the variable is significant at the significance level of 0.1

Source: own calculation.

GMM criterion: $Q=0.14412(T Q=2.88239) J$ test: Chi-square(3) $=2.88239$ [0.4101]

Test for normality of residual -

Null hypothesis: error is normally distributed

Test statistic: Chi-square(2) $=5.80105$

with $p$-value $=0.0549943$

Test for ARCH of order 1 -

Null hypothesis: no ARCH effect is present

Test statistic: $L M=0.246128$

with p-value $=P($ Chi-square $(1)>0.246128)=0.619814$

LM test for autocorrelation up to order 1 -

Null hypothesis: no autocorrelation

Test statistic: $L M F=0.980232$

with $p$-value $=P(F(1.18)>0.980232)=0.336025$

Pesaran-Taylor test for heteroskedasticity -

Null hypothesis: heteroskedasticity not present

Asymptotic test statistic: $z=0.36147$

with p-value $=0.717748$ 
Pobrane z czasopisma Annales $\mathrm{H}$ - Oeconomia http://oeconomia.annales.umcs.pl Data: 26/04/2023 14:52:54

Tab. 4. Equation3: 2-step GMM, using observations 1996-2015 (T=20)

Dependent variable: ld_BOND

Instrumented: 1d_DI ld_DI_1

Instruments: const ld_STOCK ld_NFCF ld_GDP time ld_BOND_1

HAC standard errors, bandwidth 2 (Bartlett kernel)

\begin{tabular}{|c|c|c|c|c|c|}
\hline & Coefficient & Std. Error & $z$ & & \\
\hline Const. & 0.0539322 & 0.022463 & 2.4009 & $\frac{p \text {-value }}{0.0164}$ & $* *$ \\
\hline ld_DI & 0.376372 & 0.139617 & 2.6957 & 0.0070 & *** \\
\hline 1d_DI_1 & -0.224045 & 0.117072 & -1.9137 & 0.0557 & $*$ \\
\hline \multicolumn{2}{|c|}{ Mean dependent var. } & & S.D. dependent var. & \multicolumn{2}{|c|}{0.136079} \\
\hline
\end{tabular}

$* * *$ the variable is significant at the significance level of $0.01, * *$ the variable is significant at the significance level of $0.05, *$ the variable is significant at the significance level of 0.1

Source: own calculation.

GMM criterion: $Q=0.172375(T Q=3.44751) J$ test: Chi-square $(3)=3.44751$ [0.3276]

Test for normality of residual -

Null hypothesis: error is normally distributed

Test statistic: Chi-square(2) $=0.366639$

with $p$-value $=0.832502$

LM test for autocorrelation up to order 1 -

Null hypothesis: no autocorrelation

Test statistic: $L M F=1.88538$

with $p$-value $=P(F(1.16)>1.88538)=0.189903$

Test for ARCH of order 1 -

Null hypothesis: no ARCH effect is present

Test statistic: $L M=0.418564$

with -value $=P($ Chi-square $(1)>0.418564)=0.517654$

Pesaran-Taylor test for heteroskedasticity -

Null hypothesis: heteroskedasticity not present

Asymptotic test statistic: $z=3.04951$

with $p$-value $=0.00229211$

The tests concerning results of model's estimation show that regressors and instruments were selected properly (test $\mathrm{J}$ ) and from the point of view of the normal distribution assumption, lack of autocorrelation, heteroskedasticity and ARCH effect, the model fits fairly well. The results of the model's estimation indicate a statistically and economically significant effect of the indicators of the Polish equity securities and debt securities market integration with abroad on economic growth. However, it must be noted that the effect of debt securities market integration on economic growth is stronger than in the case of the equity securities market integration with abroad (see: Tab. 2).

When it comes to the effect of equity securities market integration with foreign markets on equity market development and debt securities market integration with 
foreign markets, the former is much bigger than the latter. In both cases the relationship between integration of both markets with foreign markets and capitalization in these markets is statistically significant.

\section{Conclusions}

Results of the analysis carried out for the sake of this work allow us to state that an increase in the degree of the Polish equity securities market integration with foreign markets has a positive and fairly significant effect on the development of both the equity market development and economic growth in Poland. In the latter case the effect of this market integration with abroad is relatively small. An increase in the degree of the debt securities market integration with foreign markets also exerts a fairly significant and rather considerable effect on development of the bond market in Poland. In the case of effect on economic growth, the said effect is much weaker. The research results are also confirmed by the results obtained by other authors who investigated the issues of the effect of financial market integration on economic growth basing on panel models (some of them were referred to in point 2 of this paper).

\section{Bibliography}

Baele L., Ferrando A., Hördal P., Krylova E., Monnet C., Measuring Financial Integration in the Euro Area, "European Central Bank: Occasional Paper Series" 2004, No. 14.

Beck T., Al-Hussainy E., Financial Structure Dataset, revised September 2015, World Bank, Washington D.C 2015.

Bukowski S.I., Integracja rynków finansowych w Unii Europejskiej. Czechy, Polska, Stowacja, Stowenia, Wegry - obszar euro, Instytut Naukowo-Wydawniczy SPATIUM, Radom 2013.

Bukowski S.I., Międzynarodowa integracja rynków finansowych, Difin, Warszawa 2011.

Coricelli F., Masten A.B., Masten I., Non-Linear Growth Effects of Financial Development: Does Financial Integration Matter?, "Journal of International Money and Finance" 2008, No. 27.

Dębski W., Bujnowicz I., Model wspótzależności rozwoju systemu finansowego i wzrostu gospodarczego w Polsce, „Zeszyty Naukowe Uniwersytetu Szczecińskiego. Studia i Prace Wydziału Nauk Ekonomicznych i Zarządzania" 2008, nr 9.

Dębski W., Maciejczyk I., Wdowiński P., Growth Effects of Financial Market Development in Poland: Simulations with an Econometric Model, [in:] S.I. Bukowski (ed.), Global Challenges of the $21^{s t}$ Century, Technical University of Radom, Radom 2010.

Friedrich Ch., Schnabel I., Zettelmeyer J., Financial Integration and Growth. Is Emerging Europe Different, "EBRD Working Paper" 2010, No. 123.

Greenwood J., Jovanovic B., Financial Development, Growth, and the Distribution of Income, "NBER Working Paper" 1989, No. 3189.

Levine R., Finance and Growth: Theory and Evidence, 2005, http://faculty.haas.berkeley.edu/ross_levine/ papers/forth_book_durlauf_finngrowth.pdf [access: 15.10.2017].

Rajan R.G., Zingales L., Financial Dependence and Growth, “American Economic Review” 1998, Vol. 88(3).

Sum K., The Integration of the Financial Markets and Growth Evidence from a Global Cross-Country Analysis, "Bank i Kredyt" 2012, nr 43(3). 


\section{Integracja polskiego rynku papierów udziałowych i rynku papierów dłużnych z rynkami zagranicznymi a wzrost gospodarczy w Polsce}

Celem artykułu jest odpowiedź na pytanie, czy integracja polskiego rynku udziałowych papierów wartościowych oraz rynku papierów dłużnych z rynkami zagranicznymi wpływa na wzrost gospodarczy w Polsce. Sformułowano hipotezę badawczą, że integracja polskiego rynku udziałowych papierów wartościowych oraz integracja polskiego rynku papierów dłużnych z zagranicą wpływa w sposób statystycznie i ekonomicznie istotny na rozwój rynku kapitałowego oraz wzrost gospodarczy w Polsce. Badania z zastosowaniem modeli ekonometrycznych wykazały, że wzrost stopnia integracji polskiego rynku udziałowych i dłużnych papierów wartościowych z zagranicą wywiera pozytywny i dość znaczny wpływ zarówno na rozwój rynku akcji, jak i na wzrost gospodarczy w Polsce.

\section{Integration of Polish Equity and Debt Securities Market with Foreign Market and Economic Growth in Poland}

The aim of the research, which is the basis of this paper, is to answer the question whether integration of Polish equity and debt securities markets with foreign market influence economic growth in Poland. The following hypothesis has been put forward: integration of Polish equity and debt securities market with foreign markets has a significant impact on the capital market development and economic growth in Poland. The results of the research with implementation of econometric models confirm the hypothesis. 